\title{
PENGARUH MODEL PEMBELAJARAN CONCEPT ATTAINMENT TERHADAP HASIL BELAJAR SISWA PADA MATA PELAJARAN EKONOMI DI SMA SRIJAYA NEGARA PALEMBANG
}

\author{
Oleh: Devi Nur Ahni Oktavia Putri ${ }^{1}$, Bukman Lian $^{2}$, Depi Pramika ${ }^{3}$ \\ (UNIVERSITAS PGRI PALEMBANG) \\ devinur.okta96@gmail.com ${ }^{1}$, depi.neynda0506@gmail.com ${ }^{3}$
}

\begin{abstract}
Abstrak-Penelitian ini bertujuan untuk mengetahui pengaruh model pembelajaran concept attainment terhadap hasil belajar siswa pada mata pelajaran ekonomi di SMA Srijaya Negara Palembang. Metode penelitian yang digunakan dalam penelitian ini adalah metode eksperimen atau eksperimental pendekatan penelitian kuantitatif. Populasi dan sampel dalam penelitian ini adalah siswa kelas XI IPS dengan teknik pengambilan sampel purposive sampling. Teknik data yaitu dokumentasi, observasi, dan tes. Hasil penelitian dengan menggunakan analisis regresi linier sederhana yaitu menunjukan bahwa $t_{\text {hitung }}$ 7,183 $>t_{\text {tabel }} 1,996$, sehingga berdasarkan kriteria Ho ditolak dan Ha diterima. Berarti ada pengaruh model pembelajaran concept attainmentter hadap hasil belajar siswa pada mata pelajaran Ekonomi di Srijaya Negara Palembang. Dimana besar pengaruhnya adalah 43,8\% sedangkan sisanya $(100-43,8)=$ $56,2 \%$ dipengaruhi oleh faktor lain yang tidak dijelaskan dalam peneitian ini.
\end{abstract}

Kata Kunci: Model pembelajaran, Concept Attainment, Hasil Belajar, Ekonomi

Abstract-This study aims to determine the effect of the concept attainment learning model on student learning outcomes in economic subjects at Srijaya State High School Palembang. The research method used in this study is an experimental method or an experimental quantitative research approach. The population and sample in this study were students of class XI IPS with a purposive sampling technique. Data techniques are documentation, observation, and tests. The results of the study using the collection of regression equations namely $Y^{-}=$ $67.07+12.93 \mathrm{D}$ obtained the results of testing the hypothesis of the " $t$ " test showed that the difference count 7.183> t table 1.996, so based on the criteria Ho was rejected and $\mathrm{Ha}$ was accepted. Means there is an influence of concept attainment learning model on student learning outcomes in Economics in Srijaya, Palembang. Where the effect is $43.8 \%$ while the rest $(100-43.8)=56.2 \%$ is influenced by other factors not explained in this study.

Keywords : Concept Attainment, Learning Model, Learning Outcomes, Economi

\section{PENDAHULUAN}

Keberhasilan proses belajar mengajar dapat dipengaruhi pada penentuan suatu model pembelajaran yang baik sehingga meningkatkan ketertarikan pada suatu jenis pembelajaran ekonomi yang diajarkan, serta bagaimana cara 
pencapaian keberhasilan belajar siswa, Model yang pas yaitu model yang tepat dengan materi pada saat pembelajaran dan keadaan siswa, kelengkapan alat sekolah yang memadai serta tujuan pembelajaran sehingga dapat dilihat apakah model pembelajaran tersebut akan dapat diterapkan secara tepat sasaran. Suatu model pembelajaran yang dapat dikatakan baik adalah model yang sesuai dengan materi yang akan disampaikan, kondisi siswa, sarana dan prasarana yang tersedia serta tujuan pembelajarannya sehingga bisa dilihat apakah model yang tersedia serta tercapainya tujuan pembelajarannya sehingga bisa dilihat apakah model yang akan diterapkan efektif. Penerapan model pembelajaran yang bervariasi juga yang dimaksudkan untuk meningkatkan keberhasilan siswa dalam belajar dan peningkatan kualiatas pendidikan. Menurut Slameto dalam Martala Sari \& Apriani (2014:137) mengemukakan bahwa model mengajar guru yang kurang baik akan berpengaruh pada hasil belajar siswa yang tidak baik pula, hal tersebut terjadi apabila guru kurang persiapan, kurang menguasai materi atau saat menyajikan materi pelajaran yang kurang menarik. Sedangkan menurut Trianto dalam Januardi \& Anggi (2018:59) menjelaskan bahwa model pembelajaran sebagai suatu pendekatan yang luas dan menyeluruh serta dapat diklasifikasikan bedasarkan rujuan pembelajarananya, sintaks (pola urutannya) dan sifat lingkungan belajarnya.

Peningkatan hasil belajar perlu dirancang suatu pembelajaran yang membiasakan siswa untuk mengkonstruksi pemikirannya baik dengan guru, teman maupun terhadap materi itu sendiri. Perubahan dalam proses pembelajaran perlu dilakukan seperti menerapkan model pembelajaran inovatif dalam proses pembelajaran. Model pembelajaran yang inovatif salah satunya adalah model pembelajaran concept attainment. Konsep belajar sangat erat dengan hubungannya dengan hasil belajar. Menurut Suprijono dalam Thobrini (2016:20) hasil belajar adalah polapola, nilai-nilai, pengertianpengertian, sikap-sikap, apresiasi, dan keterampilan. Dengan demikian hasil belajar yang maksimal dapat dicapai oleh peserta didik, maka saat ini diperlukan banyak dikembangkan model pembelajaran yang berguna dan bertujuan untuk mendorong siswa dalam meningkatkan keaktifan setiap siswa didalam proses pembelajaran. Menurut Sudjana dalam Pramika \& Merlyn (2018:2) "Hasil belajar adalah suatu keberhasilan yang dimiliki peserta didik sebagai hasil pengalamannya sendiri dalam interaksi dengan lingkungannya melalui proses pelatihan, ketrampilan, ketekunan, pengetahuan yang ada dalam diri 
peserta didik. Sedangkan menurut Nana Syaodih Sukmadinata dalam Gunawan \& A'am (2018:7) berpendapat bahwa "hasil belajar merupakan relalisasi atau pribadi seseorang berdasarkan praktik atau pengalaman tertentu".

Menurut Mudjiono dalam Lestari \& Della (2018:130) "Hasil belajar merupakan hasil dari suatu interaksi tindak belajar mengajar". Sedangkan menurut Hamalik dalam Pratiwi (2018) mendefinisikan "hasil belajar yaitu bila seseorang telah belajar akan terjadi perubahan tingkah laku pada orang tersebut, misalnya dari tidak tahu menjadi tahu dan dari tidak mengerti menjadi mengerti”.

Berdasarkan hasil observasi sebelum penelitian yang dilakukan oleh peneliti menunjukkan bahwa kondisi pembelajaran pada mata pelajaran ekonomi di SMA

Srijaya Negara Palembang sudah baik. Tetapi penggunaan metode pembelajaran yang digunakan dalam proses belajar mengajar adalah metode ceramah yang diselingi dengan metode diskusi. Dengan demikian, sulit bagi siswa untuk mengembangkan kreativitas secara optimal. Melihat hal tersebut, maka solusi yang diberikan melalui penelitian ini adalah dengan menggunakan model pembelajaran concept attainment.

Menurut

Aunurrahman (2012:158)

"Model model pembelajaran yang dirancang untuk menata atau menyusun data sehingga konsep-konsep penting dapat dipelajari secara tepat dan efisien". Model ini memiliki pandangan bahwa para siswa tidak hanya dituntut untuk mampu membentuk konsep melalui proses pengklasifikasian data akan tetapi mereka juga harus dapat membentuk kemampuan konsep dengan kemampuannya sendiri.

Adapun sintaks dalam pembelajaran concept attainment yaitu Tahap Pertama penyajian data dan identifikasi contoh: (1) Guru mempresentasikan nama, (2) Siswa membandingkan ciri positif dan negatif dari contoh yang dikemukakan, (3) Siswa menyimpulkan dan menguji hipotesis, (4) Siswa memberikan arti sesuai dengan ciri-ciri esensial. Tahap kedua menguji pencapaian konsep yang meliputi: (5) Siswa mengidentifikasi tambahan contoh yang tidak memiliki nama, (6) Guru mengkonfirmasikan hipotesis, (7) konsep nama dan definisi sesuai dengan ciri-ciri esensial. Tahap ketiga, menganalisis kemampuan berfikir strategis yang meliputi: (8) Siswa mendeskripsikan pemikiranpemikiran mereka, (9) Siswa mendiskusikan hipotesis dan atribut, (10) Siswa mendiskusikan bentuk dan jumlah hipotesis.

Dengan model pembelajaran tersebut diharapkan siswa dapat menata atau menyusun data sehingga 
konsep penting dapat dipelajari secara tepat dan efisien, model ini memiliki pandangan bahwa para siswa tidak hanya dituntut untuk mampu membentuk konsep melalui proses pengklasifikasian data tetapi mereka juga harus dapat membentuk susunan konsep dengan kemampuan sendiri. Dari permasalahan yang dialami siswa yang diuraikan di atas maka peneliti mengadakan penelitian dengan judul "Pengaruh Model Pembelajaran Concept Attainment Terhadap Hasil Belajar Siswa Pada Mata Pelajaran Ekonomi di SMA Srijaya Negara Palembang".

\section{METODE PENELITIAN}

Sugiono (2016:02) mengatakan bahwa "metode penelitian pada dasarnya merupakan cara ilmiah untuk mendapatkan data dengan tujuan dan kegunaan tertentu". Sehubungan dengan masalah yang akan diteliti maka peneliti akan menggunakan metode eksperimen atau eksperimental yang merupakan pendekatan penelitian kuantitatif.

Penelitian ini, dilakukan di SMA Srijaya Negara Palembang yang berada di Jl. Ogan, Bukit Lama, Ilir Bar. I Kota Palembang, Sumatera Selatan. Adapun pelaksanaan penelitian akan dilakukan selama lebih kurang tiga minggu.

Penelitian ini dilakukan di kelas XI jurusan IPS pada semester ganjil tahun pelajaran 2019/2020. Pada penelitian ini, teknik pengumpulan data yaitu:
1. Dokumentasi

Dalam penelitian ini metode dokumentasi digunakan sebagai data pendukung untuk memperoleh jumlah kelas, jumlah siswa yang dijadikan populasi penelitian dan identitas sekolah, nilai-nilai siswa.

2. Observasi

Dalam penelitian ini observasi digunakan pada saat siswa mengikuti proses belajar mengajar yang sedang berlangsung yang bertujuan untuk melihat kesesuaian antara pelaksanaan dan rancangan penelitian dan untuk melihat keaktifan belajar siswa. Observasi dilakukan oleh peneliti pada saat melakukan penelitian.

3. Tes

Tes dilakukan bertujuan untuk mengetahui hasil belajar siswa pada mata pelajaran ekonomi. Bentuk tes yang dilakukan dalam penelitian ini adalah pilihan ganda.

\section{HASIL DAN PEMBAHASAN}

Hasil Penelitian

Deskripsi Pelaksanaan Penelitian

Penelitian ini dilakukan di SMA Srijaya Negara Palembang, mulai tanggal 29 juli 2019 sampai dengan 09 agustus 2019 yang berlokasi di Jl. Ogan Komplek FKIP UNSRI Bukit Besar Kota Palembang, Sumatera Selatan. Dengan jumlah sampel 68 yang 
terdiri dari kelas 33 siswa kelas $\mathrm{X} 1$ IPS 1 dan XI IPS 2 yang berjumlah 35 siswa. Penelitian ini dilakukan 4 kali pertemuan untuk masing-masing kelas sampel, dimana kelas XI IPS 2 menggunakan model pembelajaran concept attainment dan kelas XI IPS 1 menggunakan metode konvensional. Kegiatan belajar mengajar yang dilaksanakan di kelas pada hari senin tanggal 29 Juli- 09 Agustus 2019.

Deskripsi Hasil Observasi di Kelas Eksperimen

Berdasarkan analisis observasi belajar siswa di kelas XI IPS 2 selama kegiatan pembelajaran dapat dilihat pada tabel berikut ini :

Tabel 1. Hasil Observasi Siswa Kelas Eksperimen

\begin{tabular}{|c|c|c|c|c|}
\hline No & Interval Penilaian & Frekuensi & Persentase (\%) & Keterangan \\
\hline 1 & $85-100$ & 9 & 26 & Sangat Aktif \\
\hline 2 & $69-84$ & 26 & 74 & Aktif \\
\hline 3 & $53-68$ & 0 & 0 & Cukup Aktif \\
\hline 4 & $37-52$ & 0 & 0 & Kurang Aktif \\
\hline 5 & $<36$ & 0 & 0 & Sangat Kurang Aktif \\
\hline \multicolumn{2}{r|}{ Jumlah } & $\mathbf{3 5}$ & $\mathbf{1 0 0}$ & Aktif \\
\hline
\end{tabular}

Sumber: Diolah dari hasil penelitian

Berdasarkan data tabel 1, maka dapat dilihat bahwa dalam proses pembelajaran menggunakan model pembelajaran concept attainment siswa yang mencapai persentase $26 \%$ dengan kriteria "Sangat Aktif" sebanyak 9 siswa, kemudian siswa yang memperoleh persentase sebesar $74 \%$ dengan kriteria "Aktif" sebanyak 26 siswa, selanjutnya tidak ada siswa yang memperoleh pada kriteria "Cukup, Kurang, dan Sangat Kurang Aktif'. Jadi dapat disimpulkan siswa kelas eksperimen yang diajar dengan menggunakan model pembelajaran concept attainment keakifan siswa dalam belajar terlihat pada kategori "Aktif".

\section{Deskripsi Hasil Observasi di Kelas Kontrol}

Berdasarkan analisis observasi belajar siswa di kelas XI IPS 1 selama kegiatan pembelajaran dapat dilihat pada tabel berikut ini : 
Tabel 2. Hasil Observasi Kelas Kontrol

\begin{tabular}{|c|c|c|c|c|}
\hline No & Interval Penilaian & Frekuensi & Persentase (\%) & Keterangan \\
\hline 1 & $85-100$ & 0 & 0 & Sangat Aktif \\
\hline 2 & $69-84$ & 11 & 33 & Aktif \\
\hline 3 & $53-68$ & 20 & 61 & Cukup Aktif \\
\hline 4 & $37-52$ & 2 & 6 & Kurang Aktif \\
\hline 5 & $<36$ & 0 & 0 & Sangat Kurang Aktif \\
\hline & Jumlah & $\mathbf{3 3}$ & $\mathbf{1 0 0}$ & Cukup Aktif \\
\hline & Rata-Rata & $\mathbf{6 6}$ & & \\
\hline
\end{tabular}

Sumber: Diolah dari hasil penelitian

Berdasarkan data tabel 2, maka dapat dilihat bahwa dalam proses pembelajaran menggunakan model konvensional siswa yang mencapai persentase $0 \%$ dengan kriteria "Sangat Aktif" sebanyak 11 siswa, kemudian siswa yang memperoleh persentase sebesar 33\% dengan kriteria "Aktif" sebanyak 11 siswa, dan siswa yang memperoleh persentase $61 \%$ dengan kriteria "Cukup Aktif" sebanyak 20 siswa, selanjutnya tidak ada siswa yang memperoleh pada kriteria "Kurang, dan Sangat Kurang Aktif'. Jadi dapat disimpulkan siswa kelas kontrol yang diajar dengan menggunakan metode ceramah, tanya jawab terlihat pada kategori “ Cukup Aktif'.

\section{Deskripsi Hasil Belajar Siswa di} Kelas Eksperimen

Berdasarkan analisis data hasil belajar siswa kelas XI IPS 2 selama proses pembelajaran dapat dilihat pada tabel dibawah ini :

Tabel 3. Distribusi Frekuensi Hasil Belajar Siswa Kelas Eksperimen

\begin{tabular}{|c|c|c|c|}
\hline \multirow{2}{*}{ Angka } & \multicolumn{2}{|c|}{ Nilai Hasil Tes } & \multirow{2}{*}{ Kriteria } \\
\cline { 2 - 3 } & Frekuensi & Persentase & Sangat baik \\
\hline $86-100$ & 11 & $31,40 \%$ & Baik \\
\hline $71-85$ & 22 & $62,90 \%$ & Cukup \\
\hline $56-70$ & 2 & $5,70 \%$ & Kurang baik \\
\hline $41-55$ & 0 & $0 \%$ & Sangat kurang \\
\hline $0-40$ & 0 & $0 \%$ & \\
\hline TOTAL & $\mathbf{3 5}$ & $\mathbf{1 0 0}$ & \\
\hline
\end{tabular}

Sumber: Diolah Dari Hasil Penelitian

Berdasarkan data tabel 3, maka dapat diketahui bahwa dalam proses belajar mengajar bila menggunakan model pembelajaran concept attainment menunjukan hasil belajar sebagian besar pada kategori “Sangat Baik” (31,40\%) dan kategori "Baik" (62,90\%), dan 
paling rendah hasil belajar siswa pada kategori "Cukup" (5,70\%), selanjutnta pada kategori " Kurang Baik dan Sangat Kurang" tidak ada. Rata-rata hasil belajar siswa pada kelas eksperimen adalah 80 pada kategori "Baik". Hal ini menunjukan bahwa dengan menggunakan model pembelajaran concept attainment pada proses belajar mengajar, hasil belajar siswa berada pada kategori " Baik".

\section{Deskripsi Hasil Belajar Siswa di} Kelas Kontrol

Berdasarkan analisis data hasil belajar siswa kelas XI IPS 1 selama proses belajar mengajar dapat dilihat pada tabel dibawah ini:

Tabel 4. Distribusi Frekuensi Hasil Belajar Siswa Kelas Kontrol

\begin{tabular}{|c|c|c|c|}
\hline \multirow{2}{*}{ Angka } & \multicolumn{2}{|c|}{ Nilai Hasil Tes } & \multirow{2}{*}{ Kriteria } \\
\cline { 2 - 3 } & Frekuensi & \% & \\
\hline $86-100$ & 1 & $3 \%$ & Sangat baik \\
\hline $71-85$ & 9 & $27,30 \%$ & Baik \\
\hline $56-70$ & 21 & $63,60 \%$ & Cukup \\
\hline $41-55$ & 2 & $6,10 \%$ & Kurang baik \\
\hline $0-40$ & 0 & $0 \%$ & Sangat kurang \\
\hline TOTAL & $\mathbf{3 3}$ & $\mathbf{1 0 0}$ & \\
\hline
\end{tabular}

Sumber: Diolah dari hasil penelitian

Berdasarkan data tabel 4, maka dapat diketahui bahwa dalam proses belajar mengajar bila menggunakan model konvensional menunjukan hasil belajar sebagian besar pada kategori " Sangat Baik" (3\%) sebanyak 1 siswa dan kategori "Baik" (27,30\%) sebanyak 9 siswa, dan pada kategori “ Cukup" ( $63,60 \%$ ) sebanyak 21 siswa dan paling rendah hasil belajar siswa pada kategori "Kurang Baik" $(6,10 \%)$ sebanyak 2 siswa, selanjutnya pada kategori "Sangat Kurang" tidak ada. Rata-rata hasil belajar siswa pada kelas kontrol adalah 67 pada kategori " Cukup Baik". Hal ini menunjukan bahwa proses belajar mengajar dengan menggunakan metode seramah, tanya jawab proses belajar mengajar hasil belajar siswa berada pada kategori " Baik".

\section{Data Hasil Perbandingan Belajar Siswa Pada Kelas Eksperimen Dan Kontrol}

Berdasarkan analisis hasil belajar di atas, maka perbandingan hasil belajar siswa eksperimen dan 
kontrol dapat dilihat pada tabel dibawah ini :

Tabel 5. Distribusi Perbandingan Hasil Belajar Siswa Kelas Eksperimen Dan Kelas Kontrol

\begin{tabular}{|c|c|c|c|c|c|}
\hline \multirow{2}{*}{ Angka } & \multicolumn{4}{|c|}{ Nilai Hasil Tes } & \multirow{2}{*}{ Kriteria } \\
\hline & Eksperimen & $\%$ & Kontrol & $\%$ & \\
\hline $86-100$ & 11 & 31,4 & 1 & 3 & Sangat baik \\
\hline $71-85$ & 22 & 62,9 & 9 & 27,3 & Baik \\
\hline $56-70$ & 2 & 5,7 & 21 & 63,6 & Cukup \\
\hline $41-55$ & 0 & 0 & 2 & 6,1 & Kurang baik \\
\hline $0-40$ & 0 & 0 & 0 & 0 & Sangat kurang \\
\hline TOTAL & 35 & 100 & 33 & 100 & \\
\hline
\end{tabular}

Sumber: Diolah dari hasil penelitian

Dari tabel di atas terlihat bahwa terdapat perbedaan hasil belajar siswa kelas eksperimen dan kelas kontrol yaitu pada kelas eksperimen siswa sebagian besar berada pada kategori " Baik" sedangkan pada kelas kontrol hasil belajar siswa sebagian besar berada pada kategori “ Cukup Baik”. Dari rata-rata nilai siswa juga berbeda yaitu siswa pada kelas eksperimen sebesar 80 yang berada pada kategori "Baik" sedangkan siswa kelas kontrol yaitu 67 pada kategori "Cukup Baik". Jadi dapat disimpulkan siswa kelas eksperimen yang diajar dengan menggunakan model pembelajaran concept attainment terlihat mendapatkan hasil belajar pada kategori "Baik" dibandingkan dengan siswa kelas kontrol.

\section{Pengujian Hipotesis}

Berdasarkan hasil uji prasyarat statistik parametris yaitu uji normalitas dan homogenitas data telah memnuhi syarat, maka analisis data menggunakan statistik parametris dengan regresi linier sederhana. Statistik uji yang digunakan adalah " $\mathrm{t}$ " tes melalui regresi linier sederhana dummy variabel dengan Kesimpulan nilai $t_{\text {hitung }} 7,183>t_{\text {tabel }} 1,996$, sehingga berdasarkan kriteria Ho ditolak dan Ha diterima. Berarti ada pengaruh model pembelajaran concept attainment terhadap hasil belajar siswa pada mata pelajaran Ekonomi di Srijaya Negara Palembang . Dimana besar pengaruhnya adalah $43,8 \%$ sedangkan sisanya $(100-43,8)=$ $56,2 \%$ dipengaruhi oleh faktor lain yang tidak dijelaskan dalam peneitian ini.

\section{Pembahasan}

Berdasarkan hasil penelitian di atas menunjukan bahwa hasil belajar pada kelas eksperimen siswa yang mendapat kriteria sangat baik pada angka 86-100 sebanyak 11 orang 
(31,4\%), sedangkan pada kelas kontrol sebanyak 1 orang (3\%). Nilai dengan kriteria baik pada angka 7185 pada kelas eksperimen sebanyak 22 orang $(62,9 \%)$. Sedangkan pada nilai kelas kontrol ada 9 orang (27,3\%). Jadi dapat disimpulkan dari perbandingan nilai kelas eksperimen dan kelas kontrol terdapat perbedaan. Maka peneliti dapat menyimpulkan bahwa hasil belajar siswa pada kelas eksperimen lebih baik dari pada kelas kontrol.

Pada pengujian hipotesis yang dihitung dengan menggunakan hasil persamaan regresi yaitu $\bar{Y}=67,07+$ $12,93 \mathrm{D}$ di peroleh hasil pada pengujian hipotesis uji " $\mathrm{t}$ " menunjukan bahwa beda $t_{\text {hitung }} 7,183>t_{\text {tabel }} 1,996$,

sehingga berdasarkan kriteria Ho ditolak dan Ha diterima. Berarti ada pengaruh model pembelajaran concept attainment terhadap hasil belajar siswa pada mata pelajaran Ekonomi di Srijaya Negara Palembang . Dimana besar pengaruhnya adalah $\quad 43,8 \%$ sedangkan sisanya $(100-43,8)=$ $56,2 \%$ dipengaruhi oleh faktor lain yang tidak dijelaskan dalam peneitian ini. Hal ini membuktikan bahwa model pembelajaran concept attainment cocok diterapkan pada mata pelajaran ekonomi karena siswa dituntut berfikir kritis sehingga dapat menemukan konsep konsep baru dan dapat membedakan contoh-contoh positif dan negatif pada materi pendapatan nasional mata pelajaran ekonomi.

Hasil di atas sesuai dengan pengertian model pembelajaran menurut Aunurrahman (2012:158) "Model pencapaian/perolehan konsep adalah model pembelajaran yang dirancang untuk menata atau menyusun data sehingga konsepkonsep penting dapat dipelajari secara tepat dan efisien". Model ini memiliki pandangan bahwa para siswa tidak hanya dituntut untuk mampu membentuk konsep melalui proses pengklasifikasian data akan tetapi mereka juga harus dapat membentuk kemampuan konsep dengan kemampuannya sendiri.

Hasil penelitian tersebut sejalan dengan kajian terdahulu yang relevan yang dilakukan oleh Risdawati (2017) yang menunjukkan ada "Pengaruh Model Pembelajaran Concept Attainment Terhadap Aktivitas Dan Hasil Belajar Biologi Siswa Di Kelas XI IPA SMAN 11 Bulukumba". Adapun hasil penelitiannya yaitu data hasil posttest kelas eksperimen. Taraf signifikan yang ditetapkaan adalah $\alpha=0,050$. Dengan $\mathrm{T}$ tabel 6,314 berdasarkan pengolahan data dengan uji-t maka diperoleh $\mathrm{T}$ hitung 16,26, maka Ho ditolak HI diterima, dan sejalan dengan penelitian Selain itu juga sejalan dengan penelitian yang dilakukan Wahyu Istungingsih dan Muhammad Sabandi (2016) yang menunjukkan adanya perbedaan signifikan dimana concept 
attainment model lebih efektif dibandingkan dengan model mind mapping. "Efektivitas model pembelajaran concept attainment dan mind mapping terhadap hasil belajar siswa pada mata pelajaran ekonomi kelas XI IPS SMA Negeri 2 Karanganyar Tahun Pelajaran 2015/2016.

Dari uraian di atas membuktikan bahwa hasil belajar siswa yang meggunakan model pembelajaran concept attainment meningkat jika dibandingkan dengan menggunakan model pembelajaran convensional. Oleh karena itu, model pembelajaran concept attainment juga dapat dijadikan salah satu alternatif dalam proses pembelajaran pada mata pelajaran ekonomi. Hal tersebut terbukti bahwa siswa kelas yang diajarkan dengan menggunakan model pembelajaran concept attainment (eksperimen) memperoleh hasil belajar lebih tinggi dibandingkan kelas yang diajarkan dengan menggunakan model pembelajaran konvensional (kontrol).

\section{KESIMPULAN DAN SARAN Kesimpulan}

Berdasarkan hasil analisis data mengenai pengaruh model pembelajaran concept attainment terhadap hasil belajar siswa pada mata pelajaran ekonomi di SMA Srijaya Negara Palembang disimpulkan sebagai berikut :

1. Berdasarkan distribusi hasil belajar ternyata pada kelas eksperimen siswa yang mendapat rata-rata nilai hasil belajar pada kelas eksperimen memperoleh nilai 80 yang berada pada kategori baik lebih besar dari rata-rata hasil belajar kelas kontrol yaitu 67 pada kategori baik. Maka peneliti dapat menyimpulkan bahwa hasil belajar siswa pada kelas eksperimen lebih baik dari pada kelas kontrol.

2. Berdasarkan hasil persamaan regresi yaitu $\bar{Y}=67,07+$ $12,93 D$ di peroleh hasil pada pengujian hipotesis uji " $t$ " menunjukan bahwa $t_{\text {hitung }} 7,183>t_{\text {tabel }} 1,996$, sehingga berdasarkan kriteria Ho ditolak dan Ha diterima. Berarti ada pengaruh model pembelajaran concept attainment terhadap hasil belajar siswa pada mata pelajaran Ekonomi di Srijaya Negara Palembang . Dimana besar pengaruhnya adalah $43,8 \%$ sedangkan sisanya dipengaruhi oleh faktor lain yang tidak dijelaskan dalam peneitian ini.

\section{Saran}

Berdasarkan hasil penelitian yang telah dilakukan, maka peneliti memberi saran sebagai berikut :

1. Bagi sekolah, untuk meningkatkan kualitas pembelajaran ekonomi hendaknya sekolah memberikan pelatihan keterampilan mengajar kepada 
guru agar dapat menerapkan model pembelajaran yang inovatif yang dapat merangsang kreatifitas siswa serta dapat mengembangkan cara pembelajaran di sekolah tersebut sehingga dapat meningkatkan kualitas pendidikannya.

2. Bagi guru khususnya mata pelajaran ekonomi model pembelajaran concept attainment agar dapat disajikan alternatif guru dalam kegiatan belajar mengajar sehingga diharapkan dapat meningkatkan hasil belajar siswa.

3. Bagi siswa, dengan menggunakan model pembelajaran yang diberikan dapat diciptakan situasi belajar yang menarik dan merangsang siswa untuk aktif dalam belajar, sehingga dapat meningkatkan hasil belajar.

4. Bagi kalangan akademis, dapat memberikan sumbangan informasi serta sumber bacaan bagi peneliti yang akan dating.

\section{DAFTAR PUSTAKA}

Aunurrahman. 2012. Belajar dan Pembelajaran. Bandung: Alfabeta.

Gunawan, Hendri \& A'am Rifaldi Khunuaifi. 2018. Upaya Meningkatkan Hasil Belajar Peserta Didik dengan Menggunakan Media Audio Visual Pada Pelajaran Bahasa Indonesia Kelas V SDN-5 Menteng Palangka Raya. BITNET Jurnal Pendidikan Teknologi Informasi. Volume 3
Nomor $1 . \quad$ Online

(http://journal.umpalangkaraya. ac.id/index.php/bitnet). $\quad \mathrm{Di}$ akses Rabu,02 Januari 2019 Pukul 19.15 WIB

Januardi \& Anggi Gustina. 2018. Pengaruh Model Pembelajaran Reciprocal Learning Terhadap Hasil Belajar Mata Pelajaran Ekonomi di SMA Bakti Bangsa Air Saleh. Jurnal Neraca. Volume 2 No.1, juni 2018. Di akses Rabu, 02 Januaru 2019 Pukul 19.10 WIB. Online (Http://jurnalneraca.univpgripalembanng.ac.id)

Lestari, Neta Dian \& Della Sari. 2018. Pengaruh Media Pembelajaran Visual Terhadap Hasil Belajar Ekonomi Siswa. Jurnal Neraca. Vol 2 No 2 Desember 2018. Online (Http://jurnalneraca.univpgripalembanng.ac.id). Senin, 23 April 2019 Pukul 09.40 WIB

Pramika, Depi \& Merlyn Widalismana. 2018. Buku Saku Sebagai Media Pembelajaran Matematika Ekonomi di Program Studi Pendidikan Akuntansi FKIP Universitas PGRI Palembang. Jurnal Promosi. Volume 6 No.2 (2018) 1-12. Online (Http://ojs.fkip.ummetro.ac.id). Di akses Rabu, 02 Januari 2019 Pukul 19.00 WIB.

Pratiwi, Nova. 2018. Meningkatkan Hasil Belajar Siswa Melalui Metode Investigasi Kelompok Dengan Variabel Moderator Kemandirian Belajar. Prosiding Seminar Nasional.Online (Http://jurnalneraca.univpgri- 
palembanng.ac.id). Di akses Rabu, 02 Januari 2019 Pukul 19.00 WIB.

Risdawati dkk. 2017. Pengaruh model pembelajaran concept attainment terhadap aktivitas dan hasil belajar biologi siswa di kelas XI IPA SMAN 11 Bukulumba. Jurnal Biotek. Volume 5 No 2. (Http://journal .Uin-aluddin.ac.id). Diakses Rabu, 02 Januari 2019 Pukul 19.14 WIB

Sari, Martala \& Jeli Apriani. 2014. Pengaruh model pembelajaran concept attainment terhadap hasil belajar siswa kelas VII pada konsep sistem pernafasan (studi eksperimen di SMPN 2 Gunung Sahilan Tahun Pelajaran 2013/2014. Universitas Lancang Kuning. Jurnal Biolectura. Volume 01, Nomor 02.

(http://journal.unilak.ac.id). Diakses Rabu, 02 Januari 2019 19.14 WIB.

Sugiono. 2016. Metode Penelitian Kuantitatif, Kualitatif, dan $R \& D$. Bandung: Alfabeta. 